\title{
Leseopplæring i norskfagets begynneropplæring med fokus på fagspesifikk lesekompetanse
}

\author{
Anne Håland $\star$, and Trude Hoel \\ Nasjonalt senter for leseopplaring og leseforsking, Universitetet i Stavanger, Norge
}

\begin{abstract}
Distinksjonen knyttet til generell og fagspesifikk lese- og skriveopplæring i fagene har fått fornyet interesse både i norsk og internasjonal sammenheng. Denne artikkelen diskuterer hva dette betyr i norskfagets begynneropplæring, og søker med dette å supplere litteraturen som finnes om lesing av skjønnlitteratur. Vi stiller spørsmålet: Hvordan posisjonerer elever på 1. trinn seg som litterære lesere? Spørsmålet utforskes gjennom klassesamtaler rundt to utvalgte bildebøker med innlagte lesestopp, basert på teorier om hva det vil si å lese skjønnlitteratur, og da særlig Judith Langers teorier (2005) om forestillingsverdener. Utdragene fra klassesamtalene viser at elevene er i stand til å posisjonere seg som litterære lesere og utforske tekster på en fagspesifikk måte.
\end{abstract}

Nøkkelord: Fagspesifikk leseopplaring; fagovergripende leseopplcering; forestillingsverdener; klassesamtale; skjønnlitteratur; begynneropplaring

\begin{abstract}
There has been a renewed interest in the distinction between content area literacy and disciplinary literacy concerning reading and writing instruction within school subjects, both in Norway and internationally. This article discusses the implications for early instruction in Norwegian language learning and seeks to supplement the current literature concerning fiction reading. We ask the question: How do first grade students position themselves as readers of literature? This question is explored through classroom discussions regarding two selected picture books, with planned reading stops, based on theories on what literature reading involves, in particular Judith Langer's (2005) theories on envisionments. Our excerpts from classroom discussions display that the students are able to position themselves as literary readers and explore the texts in a discipline specific manner.
\end{abstract}

Keywords: Disciplinary literacy; content area literacy; envisionment building; classroom discussions; fictional literature; early literacy

Received: October 2015; Accepted: February 2016; Published: April 2016

${ }^{\star}$ Correspondence to: Anne Håland, Nasjonalt senter for leseopplæring og leseforsking, Universitetet i Stavanger, 4036 Stavanger, Norge. Email: anne.haland@uis.no 


\section{Introduksjon}

Fonemisk bevissthet, leseflyt og utvikling av vokabular har tradisjonelt hatt et stort fokus i begynneropplæringa i lesing, både internasjonalt (National Reading panel, 2000) og i nordisk sammenheng (Taube, Fredriksson \& Olofsson, 2015). Ferdighetene som løftes fram i disse rapportene kan sees på som generelle og uavhengige av fag og fagenes egenart. I denne artikkelen ønsker vi å se nærmere på leseopplæring i norskfagets begynneropplæring. Vi forstår leseopplæring i norskfagets begynneropplæring også som et uttrykk for en fagspesifikk lesekompetanse (Shanahan \& Shanahan, 2008, 2012). Fagspesifikk lesekompetanse innebærer det å bli fortrolig med tekster som er typiske i faget og hvor det å forstå, lære og utøve et fag ikke kan sees uavhengig av å skape mening med språket (Berge, 2005). Det grunnleggende målet med norskfaget er at «elevene skal settes i stand til fagrelevant skriving, lesing og muntlighet» (ibid. s. 163). Fagrelevant lesing, skriving og muntlighet har fått lite oppmerksomhet i begynneropplæringa. Studier av leseopplæring i norskfaget, også for eldre elever, rapporterer at fagspesifikk leseopplæring tidvis er mangelfull og fraværende, som at undervisningen i litteratur i norskfaget har hovedfokus på tilfeldig utvalgte innholdselementer eller på ukjente ord, og at det i liten grad blir brukt tekstanalytiske begreper (Sandvik \& Buland, 2013). Bruk av tekstanalytiske begreper kan være sentrale i norskfaget fordi teksten er det som studeres, og fordi faglighet bl.a. viser seg i måten elevene bruker språket på (Hetmar, 2009; Krogh, 2011). I tillegg har elevene kvalitativt bedre tekstsamtaler dersom de får spesifikke analytiske kategorier å tenke i (Rødnes, 2011). Samtaler om litteratur kan forstås som en særegen arbeidsform «som har som føremål å undersøkje litterære tekstar med utgangspunkt i desse erfaringane» (Aase, 2005, s. 106). Den litterære samtalen innebærer en utforskende diskusjon omkring en tekst som baserer seg på leseopplevelser og nærlesing, og «elevene trenger både undervisning, modellering og trening for å forstå hva en litterær samtale faktisk går ut på og hvordan de skal gjennomføre den.» (Hennig, 2012, s. 121). ${ }^{1}$

Med denne studien ønsker vi å synliggjøre at en mer fagspesifikk tilnærming i møte mellom elever og litteratur også er relevant for de yngste elevene. Vi ønsker å undersøke hvordan elevene på 1. trinn posisjonerer seg som litterære lesere når de i klassesamtaler om litteratur engasjerer seg i en fagspesifikk tilnærming.

\section{Generell og fagspesifikk leseopplæring}

Generell og fagspesifikk leseopplæring blir særlig i amerikansk forskningslitteratur omtalt som content area literacy og disciplinary literacy. Content area literacy blir forstått som «the ability to use reading, writing, talking, listening, and viewing to learn subject matter in a given discipline (Vacca, Vacca, \& Mraz, 2011, s. 16). Content area literacy innebærer altså at elevene bruker bl.a. lese- og skriveaktiviteter som støtte i læreprosessen. Mange av disse lese- og skriveaktivitetene kan være av

\footnotetext{
${ }^{1}$ Hennig (2012) knytter modellering her til lesing i lesesirkler, men vi mener at slik modellering og trening er like relevant i klassesamtaler om litteratur.
} 
generell karakter og overføres fra fag til fag, for eksempel det å ta notater og stille spørsmål til tekst. I leseopplæringa kan en content area-tilnærming medføre bruk av generelle kognitive strategier slik som hukommelsesstrategier, organiseringsstrategier, utdypingsstrategier og overvåkingsstrategier (Weinstein \& Maier, 1986). Slik vi tolker det, kan generelle hukommelsesstrategier f.eks. komme til uttrykk ved at elevene blir bedt om å gjenfortelle innholdet i en tekst, og utdypingsstrategier kan eksempelvis være at elevene blir bedt om å fokusere på ord de ikke forstår.

Disciplinary literacy blir forstått som «the ability to engage in social, semiotic, and cognitive practices consistent with those of content experts» (Fang, 2012, s. 19). I lese- og skriveopplæringa innebærer disciplinary literacy at elevene leser og skriver tekster som ligner på de som eksperter bruker. Det vil blant annet bety at lese- og skriveaktivitetene vil være forskjellige fra fag til fag, nettopp fordi fagene har ulike tekster og nærmer seg tekstene på ulike måter. Michael Carter (2007) bruker uttrykket «knowing, doing and writing in the disipline» om det å skrive $\mathrm{i}$ ulike fag. Med det mener han at bestemte måter å skrive på er lenket til bestemte måter å tenke på som igjen er koblet til bestemte måter å agere og handle på. Litt forenklet kan en si at lesing av skjønnlitteratur i norskfaget prøver å etterligne måten eksperter leser litteratur på, for eksempel ved at elevene ser på de litterære tekstene med et analytisk blikk, og stiller spørsmål om hva tekstene prøver å fortelle og hvordan dette blir uttrykt. Et slikt faglig møte kan skisseres med utgangspunkt i spørsmålet «Hvem sier hva og hvordan?»(Skaftun, 2009). I et intervju med literacyforskerne Timothy og Cynthia Shanahan tar sistnevnte til orde for at elevene i møte med litteraturundervisning bl.a. må få anledning til å posisjonere seg i retning av å være litteraturvitere "[...] ask the student to participate in the reading more as a literary critic than a student» (Shanahan \& Shanahan, 2014, s. 630). Shanahan (2015) gir også noen føringer for hvordan en kan invitere elevene til å lese tekster på en måte som minner om slik litteraturvitere leser tekster. Hun foreslår blant annet å sammenligne tekster og lete etter mønster i og mellom tekster, å bruke det faglige språket som hører til i litteraturfaget og å lese tekster for å få større forståelse for menneskelig erfaring.

Distinksjonen knyttet til generell og fagspesifikk lese- og skriveopplæring i fagene har fått fornyet interesse både i norsk og internasjonal sammenheng. I Ludvigsenutvalgets utredning «Fremtidens skole» (NOU, 2015) legges det stor vekt på dybdelæring i fagene. Med dybdelæring forstår vi bl.a. det å bli fortrolig med tekstene i faget. Eksplisitt leseopplæring knyttet til fagenes egne tekster mener vi kan fremme slik læring. Dybdelæring i norskfaget kan dermed nettopp være lesing av skjønnlitterære tekster - hvor teksten står i sentrum og utgjør selve studieobjektet (Nielsen, Gouvervennec \& Skaftun, 2014). I «Fremtidens skole» etterspørres også kommunikative fagovergripende kompetanser som kan oppfattes som mer generelle kompetanser på tvers av fag, og i rapporten framheves begrepene fagspesifikk og fagovergripende som viktige analytiske verktøy i utviklingen og fornyelsen av fag i skolen.

Internasjonalt foregår det en diskusjon om hvorvidt yngre elever og elever som strever med lesing har utbytte av spesifikke lese- og skrivepraksiser, om de ikke heller først burde bli introdusert for generelle literacypraksiser som kan overføres til en rekke fag (Shanahan \& Shanahan, 2008; Moje, 2008; Heller, 2011; Fagella-Luby, 
Graner, Desbler \& Drew, 2012; Håland, 2016). Shanahans (2008) er blant de som etterlyser «disiplinary literacy» på mellomtrinnet og i ungdomsskolen (middle and secondary school settings). De får støtte av Elisabeth Moje (2008) som ønsker et «call for change», og med det mener hun at elever i større grad bør møte lese- og skivepraksiser som er en del av fagets literacypraksis, i stedet for å bruke generelle strategier i møte med alle typer tekster. På den andre siden finnes en rekke kritiske røster mot å dreie lese- og skriveopplæringen i en retning av fagspesifikk lese- og skriveopplæring. Rafael Heller (2011) kritiserer Moje, og mener at spesialiserte leseog skrivepraksiser er best egnet for de høyt presterende elevene, og at slike praksiser ikke tar hensyn til de elevene som strever med lesing og skriving. Heller får støtte for denne kritikken (Fagella-Luby, Graner, Desbler \& Drew, 2012). Fagella-Luby et al. kaller disciplinary literacy brukt i møte med elever som strever, for «building a house on sand» (2012, s. 81).

Discilinary literacy er en rimelig ung fagtradisjon som til nå primært har befattet seg med ungdomsskoleelever og deres lese- og skriveopplæring (Damico, Baildon, Exter \& Guo, 2009; Moje, 2008; Monte-Sano, 2010; Monte-Sano, De La Paz \& Felton, 2014). Men det finnes de som har en diciplinary literacy-tilgang til fag også i studier av yngre elever (Juel, Hebard, Haubner \& Moran, 2010). Med denne artikkelen ønsker vi å supplere forskningslitteraturen knyttet til disciplinary literacy og litteraturen som finnes om det å utvikle elevene som lesere i norskfagets begynneropplæring. Vi stiller spørsmålet: Hvordan posisjonerer elever på 1. trinn seg som litterære lesere i møte med skjønnlitterære tekster?

Vi vil synliggjøre at en mer fagspesifikk tilnærming i møte mellom elever og litteratur også er aktuell for de yngste elevene. Vi ønsker å undersøke hvordan elevene på 1. trinn posisjonerer seg som litterære lesere når de møter en fagspesifikk tilnærming til litteratur gjennom lesing av to konkrete bildebøker, Dragejakten av Bjørn Ousland (2011) og Barbie-Nils \& pistolproblemet av Kari Tinnen og Mari Kanstad Johnsen (2011).

\section{Å posisjonere seg som litterær leser}

Å posisjonere seg forstår vi som å være en del av en diskursiv praksis (Harrè \& Langenhove, 1999). En diskursiv praksis, som en litterær samtale, kan en frivillig være en del av, eller en kan være tvunget til å være en del av den (ibid.). I skolen er det forventet at elevene går inn $\mathrm{i}$ en rekke diskursive praksiser nettopp - eller blant annet - for å lære seg de ulike fagenes måter å lage mening på.

Å posisjonere seg som litterær leser kan komme til uttrykk på ulike måter, og det teoretiske utgangspunktet for denne studien drar veksler på flere litteraturteoretiske tilnærminger. Å posisjonere seg som litterær leser kan f.eks. innebære at eleven i møte med tekster er aktiv og medskapende (Iser, 1974). I denne aktive medskapingen søker leseren å fylle tomrom i teksten ved blant annet å bygge på argumenter for ulike tolkninger som finnes i teksten, ved å stille spørsmål og ved å framsette hypoteser om mulige tolkningsalternativer. Noen ganger vil den aktivt medskapende leseren fokusere på detaljer, andre ganger på helheten i teksten, eller ved å forsøke å 
se detaljene i lys av helheten (Kittang \& Aarseth, 1979). Andre ganger vil den aktivt medskapende leseren søke å finne ut hva teksten «dreier seg om» (Hetmar, 2001, s. 16), da vil leseren tolke den konkrete handlingen som et uttrykk for en tematikk på et mer overordnet nivå. Den aktivt medskapende leseren vil, avhengig av litterære preferanser, også kunne relatere tekster til andre tekster han har lest eller sett/hørt og se teksten i lys av intertekstuelle referanser (Kristeva \& Moi, 1986). Andre ganger kan leseren se sammenhenger mellom litteraturen og eget liv, litteraturen og andre tekster og litteraturen og viten om verden (Harvey \& Goudvis, 2007). Slike koblinger mellom litteraturen og noe utenfor litteraturen (leseren selv, tekster og verden) vil bli formet av leserens erfaringer, alder etc., det Iser kaller leserens disposisjoner (Iser, 1974, s. 279). Det vil si at unge lesere som førsteklassinger vil fylle tomrom, sette fram hypoteser og være aktive og medskapende med utgangspunkt i sin erfaringshorisont. Leseren danner seg forestillinger både på veg inn i teksten, under selve lesingen og etter at lesingen er avsluttet (Langer, 2005).

Den amerikanske litteraturteoretikeren Judith Langer (2005) skiller mellom fire ulike typer av forestillingsverdener. ${ }^{2}$

1. Å være utenfor på vei inn

I denne fasen er leseren utenfor teksten og prøver å danne seg forestillinger om hva teksten kommer til å handle om. Slike forestillinger kan eksempelvis være knyttet til tittelen på boka, som Dragejakten (Ousland, 2011), eller forestillingene kan dannes med utgangspunkt i forventninger leseren eventuelt måtte ha med utgangspunkt $\mathrm{i}$ framsida på ei bildebok som Barbie-Nils $\mathcal{E}$ pistolproblemet (Tinnen \& Kanstad Johnsen, 2011). Selve evnen til å danne seg forestillinger vil være avhengig av personlige erfaringer og kunnskaper leseren måtte ha om eksempelvis drager, Barbie eller pistoler, altså leserens disposisjoner (jf. Iser).

\section{2. Å være i og bevege seg gjennom}

I denne fasen søker leseren å danne seg forestillinger mens han leser. Slike forestillinger kan komme til uttrykk på ulike måter. Forestillingene kan dannes når leseren søker å koble nye opplysninger til det han allerede har lest, eller ved at han eksempelvis reflekterer over karakterenes tanker og handlinger. Slik vil leserens forestillinger stadig veksle mellom helhet og del. Leseren danner også forestillinger gjennom hypoteser om hva som kommer til å skje videre i teksten. I lesingen av bildeboka Dragejakten (Ousland, 2011) kan slike forestillinger komme til uttrykk ved at en danner seg et indre bilde av hvem personene i fortellingen er: den snille kongen, den bortskjemte prinsessen, den farlige dragen og den glade Askeladden. Slike forestillinger blir dannet både med utgangspunkt i hvordan personene er beskrevet, handlingene deres og ikke minst hvordan fargevalg og perspektiv i bildene understreker personligheten til karakterene i fortellingen.

3. Å stige ut og tenke over det en vet

\footnotetext{
${ }^{2}$ Se Skaftun (2009) for en diskusjon av Langers teori i litteraturfaglig lys.
} 


\section{Anne Håland og Trude Hoel}

I denne fasen lager leseren forestillinger ved å koble teksten til noe kjent. Slike forestillinger kan være knyttet til en tematikk og det teksten dreier seg om (jf. Hetmar) eller kunnskaper en har om verden (jf. Harvey og Goudvis). I lesingen av Barbie-Nils E pistolproblemet (Tinnen og Kanstad Johnsen, 2011) kan spørsmål som fokuserer på tematikken i bildeboka, hva vil denne bildeboka egentlig fortelle, være eksempel på spørsmål som kan stimulere leseren til å stige ut at boka og tenke over det en vet.

4. Å stige ut av og objektivere leseopplevelsen

I denne fasen distanserer leseren seg fra teksten og søker å se tekst og bilder i et mer analytisk perspektiv. Det kan tenkes at en kobler teksten til andre tekster en har lest, eller at en ser forfatterens håndverk og måter å skrive og bruke bilder på. Det å analysere bildeboka Dragejakten (Ousland, 2011) i lys av andre eventyrtekster kan være én måte å stige ut av teksten og objektivere leseopplevelsen på.

Disse fire fasene som Langer skisserer, er ikke tenkt som et uttrykk for at lesingen er lineær og hvor leseren beveger seg fra den ene fasen til den neste. Det kan godt tenkes at leseren i lesingen aldri er innom fase tre eller fire. Det kan også tenkes at lesingen og forståelsen stopper opp og at leseren derfor, til tross for at han er midt i teksten, fremdeles vil kjenne seg utenfor og på vei inn. For læreren kan Langer sine teorier om forestillinger inspirere til å lage ulike typer spørsmål, slik at en sikrer at elevene får anledning til å tolke tekster i stedet for å redusere tekstlesingen til kontrollspørsmål og handlingsreferat. I norsk skole er det god grunn til å bruke fagspesifikke nærlesningsspørsmål som inviterer til utforskning av tekster, fordi forskning har vist at slik nærlesing nærmest er fraværende fram til og med ungdomsskolen (Fjørtoft, 2013; Sandvik, Engvik, Fjørtoft m.fl., 2012; Sandvik \& Buland, 2013).

For å undersøke hvordan elevene posisjonerer seg som faglige litterære lesere i begynneropplæringa, måtte vi gi elevene mulighet til å lese, tolke og utforske tekst. Det var utgangspunktet for designet av studien.

\section{Studien}

Med utgangspunkt i forskningsspørsmålet «Hvordan posisjonerer elevene seg som litterære lesere på 1. trinn?» designet vi en casestudie (Yin, 2009). Designet er laget slik at elevene skal ha muligheter til å posisjonere seg som litterære lesere, og slik at det skal være mulig for oss å se på hvilke måter deres litterære lesekompetanse kommer til uttrykk.

Vi designet klassesamtaler med utgangpunkt i to utvalgte bildebøker, hvor den ene klassen leste Barbie-Nils $\mathcal{E}$ pistolproblemet (Tinnen \& Kanstad Johnsen, 2011) og den andre klassen leste Dragejakten (Ousland, 2011). Vi valgte å ta utgangspunkt i bildebøker hvor både tekst og bilder bidrar til elevenes meningsskaping, og hvor elevene i en høytlesingssituasjon kan forholde seg aktivt (og selvstendig) til boka uten å kunne lese selv. Bildebøkene er også valgt fordi vi mener de har et potensiale for klassesamtaler, om enn på ulike måter. Barbie-Nils $\mathcal{E}$ pistolproblemet (Tinnen \& Kanstad Johnsen, 2011) tematiserer gutteleker og jenteleker, forventninger og fordommer på en måte som vi tror barn kan kjenne seg igjen i. Boka forteller historien 
om Nils som ønsker seg ei Barbie-dukke, og faren til Nils, som heller vil at Nils skal ønske seg en pistol. I lekebutikken blir Nils og farens ønsker satt på prøve. Dragejakten (Ousland, 2011) bygger på gjenkjennelige tekstmønstre, særlig hentet fra eventyrsjangeren og tegneserier. Boka er en nyskrevet Espen Askeladden-fortelling om ei bortskjemt prinsesse som ønsker seg en drage, og fortellingen viser - gjennom tekst og bilder - hvor galt dette går, særlig for prinsessa. Bøkene var ukjente for elevene i skolesammenheng, men at tre av elevene hadde lest éi av bøkene tidligere, kan vi se av materialet.

For å få svar på forskningsspørsmålet designet vi en studie som skulle gi rom for at elevene kunne posisjonere seg som litterære lesere. Designet er laget for å gi oss svar på spørsmålet vårt, ikke for å danne en norm for hvordan lærere skal lese disse to utvalgte bildebøkene. Vi tok utgangspunkt i Langers teori om forestillingsverdener og laget ulike spørsmål til hver av hennes kategorier, som vi så overførte til de to utvalgte bøkene. Spørsmålene vi laget er fagspesifikke på den måten at de gir elevene muligheter til å være aktive medskapere av tekst, sette fram hypoteser («Hva tror du boka handler om?»), fokusere på tematikk og hva teksten dreier seg om («Hva tror du denne fortellingen vil fortelle deg?»), tolke personer og handling i lys av helhet og detaljer i teksten («Hvorfor tror du personen X sier/handler/tenker slik?»), se teksten i lys av andre tekster («Minner dette deg om noe du har lest/hørt/sett tidligere?») og fokusere på forfatterens språklige håndverk («Er det noe du legger spesielt merke til med språket i fortellingen?»). Spørsmålene er tilpasset Langers teorier om forestillingsverdener og derfor blir de stilt på bestemte måter som kan virke styrende for elevens responser og begrensende for lærernes handlingsrom. Spørsmålene kunne også satt fokus på andre deler av bøkene enn de vi har valgt, eksempelvis samspillet mellom tekst og bilde.

\begin{tabular}{|c|c|c|c|}
\hline $\begin{array}{l}\text { Å være utenfor } \\
\text { på veg inn }\end{array}$ & $\begin{array}{c}\AA \text { A være i og bevege } \\
\text { seg gjennom }\end{array}$ & $\begin{array}{c}\text { Å stige ut og tenke } \\
\text { over hva en vet }\end{array}$ & $\begin{array}{c}\text { Å stige ut og objektivere } \\
\text { leseopplevelsen }\end{array}$ \\
\hline $\begin{array}{l}\text { 1. Hva ser du på } \\
\text { bildet? } \\
\text { 2. Er det noe du } \\
\text { legger merke til i } \\
\text { bildet? } \\
\text { 3. Hva tror du boka } \\
\text { handler om? } \\
\text { 4. Hva tenker du på } \\
\text { når du hører } \\
\text { tittelen? }\end{array}$ & $\begin{array}{l}\text { 5. Hva tror du skjer videre? } \\
\text { Hvorfor tror du det? } \\
\text { 6. Hvordan er } \\
\text { hovedpersonen/e? } \\
\text { 7. Hvor i fortellingen synes } \\
\text { du det er mest } \\
\text { spennende? Hvorfor } \\
\text { akkurat her? } \\
\text { 8. Hva tror du bildet/ene vil } \\
\text { fortelle? } \\
\text { 9. Hva tror du det betyr når } \\
\text { det i teksten står ...? }\end{array}$ & $\begin{array}{l}\text { 10. Hva tror du denne } \\
\text { fortellingen vil fortelle } \\
\text { deg? } \\
\text { 11. Er denne fortellingen } \\
\text { morsom/spennende/ } \\
\text { trist/rar etc.? Hvorfor? } \\
\text { 12. Ble du sint på/glad i/ } \\
\text { redd for/syntes synd på } \\
\text { noen av personene? } \\
\text { 13. Minner denne teksten } \\
\text { deg om noe du har } \\
\text { opplevd? } \\
\text { 14. Hvorfor tror du } \\
\text { personen } \mathrm{X} \text { sier/ } \\
\text { handler/tenker slik. . ? }\end{array}$ & $\begin{array}{l}\text { 15. Hvorfor tror du denne } \\
\text { teksten er skrevet/laget } \\
\text { akkurat slik? } \\
\text { 16. Er det noe du legger } \\
\text { spesielt merke til med } \\
\text { språket i fortellingen? } \\
\text { 17. Minner dette deg om } \\
\text { noe du har lest/hørt/sett } \\
\text { tidligere? } \\
\text { 18. Hvorfor tror du disse } \\
\text { bildene er i boka? }\end{array}$ \\
\hline
\end{tabular}


Med utgangspunkt i bøkene laget vi en manual til læreren som gav tydelige føringer for hvordan hver bok skulle leses med innlagte lesestopp og med angitt tilhørende spørsmål. Ut over dette ble det ikke gjort felles forberedelser til gjennomføringen.

Lesingen ble gjennomført som klassesamtaler, og med klassesamtaler forstår vi samtaler «(...) som uttrykkjer leseerfaringar, og som har som føremål å undersøkje litterære tekstar med utgangspunkt i desse erfaringane» (Aase 2005, s. 106.). Klassesamtalen ble valgt primært fordi elevene ikke kunne lese selv. Dessuten kan manglende samtalestøtte fra en voksen føre til at yngre barn ikke deltar i samtaler (Hoel, 2014). Vi var dessuten på jakt etter elevenes responser. Det var elevenes responser som skulle gi oss svar på forskningsspørsmålet, og responsene fikk vi tilgang til gjennom lydopptak av to klassesamtaler.

Lesingen ble gjennomført av lærerne i to 1 . klasser (elevene var 5 og 6 år gamle), og det var henholdsvis 14 og 22 elever i klassene. Lærerne hadde meldt seg frivillig til å gjennomføre studien. Læreren leste høyt mens elevene satt «på ringen», dvs. to stolrekker i en bue rundt læreren. Lærerne tok lydopptak av klassesamtalene. Disse opptakene ble senere transkribert av oss. Lydopptakene er anonymisert, det er ikke mulig å gjenkjenne elevene og i materialet skiller vi heller ikke mellom enkeltelever. ${ }^{3}$ Det er altså de to konkrete bildebøkene, manualen vi laget til disse og transkriberte lydopptak av klassesamtalene som utgjør materialet i denne studien.

Materialet er analysert for å finne svar på hvordan elevene posisjonerer seg som litterære lesere når de er utenfor på veg inn i teksten, gjennom tekstlesingen, på veg ut av teksten og ved å objektivere leseopplevelsen. Utvalget av spørsmål og elevresponser i den følgende presentasjonen er gjort for å eksemplifisere elevenes ulike måter å posisjonere seg på som litterære lesere innenfor Langers fire hovedkategorier. I det følgende vil vi presentere et utvalg spørsmål, med påfølgende elevresponser, for å illustrere den diskursive praksisen.

\section{Hvordan elevene posisjonerer seg som litterære lesere på 1. trinn}

\section{Utenfor på veg inn i teksten}

De transkriberte lydopptakene viser hvordan elevene på ulike måter danner seg forestillinger når de møter tekstene. I de to lesesituasjonene ser vi for eksempel at elevene setter fram ulike hypoteser om hva de tror bøkene handler om. Klassen som skal lese Dragejakten (Ousland, 2011), studerer framsida av boka, og læreren stiller spørsmålet: «Hva tenker du når du hører tittelen på boka Dragejakten»? (spørsmål 4).

En elev framstiller en hypotese basert på tittelen: «At jegeren skal jakte på dragen». En annen elev baserer sin hypotese på illustrasjonen i samspill med tittelen (ikonoteksten): «Dragen prøver å ta prinsessen». I illustrasjonen ser vi tre personer: en gutt til venstre, en konge til høyre og i midten ei jente i rosa kjole, med lange fletter, gullkrone og vidåpen munn - som i et skrik. I bakgrunnen ruver en mørk granskog, og over skogen ser vi omrisset av en diger drage mot en rød bakgrunn.

\footnotetext{
${ }^{3}$ Prosjektet behandler ikke personopplysninger og er dermed ikke meldepliktig til NSD.
} 


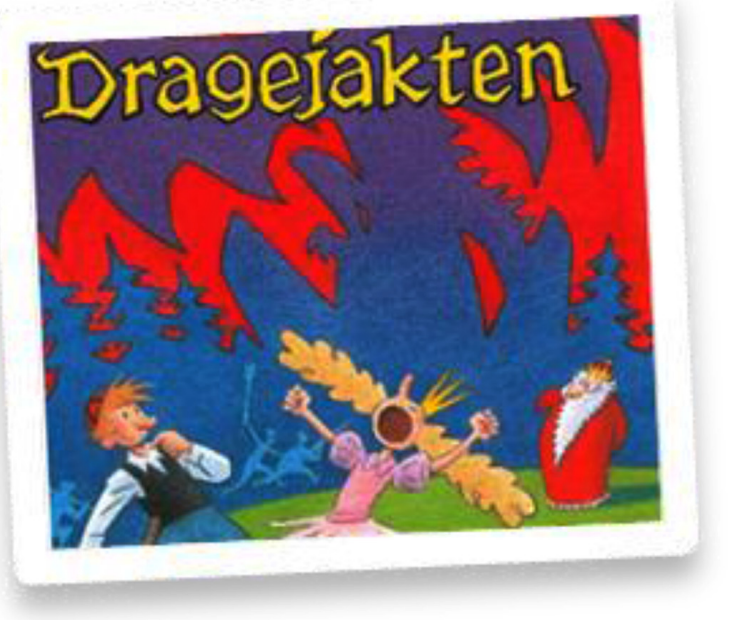

Bilde 1. Gjengitt fra Ousland (2011) med tillatelse fra illustratør og forlag.

Elevenes hypoteser er begge troverdige fortolkninger, og hypotesedannelsene er eksempler på det Langer kaller for «å være utenfor på veg inn» $\mathrm{i}$ teksten.

\section{Gjennom tekstlesingen}

I materialet finner vi også en rekke eksempler på «å være i og bevege seg gjennom teksten». Elevene som leser Dragejakten (Ousland, 2011) danner seg forestillinger om hovedpersonene i boka. Læreren spør: «Hvordan er hun prinsessen?» (spørsmål 6). Elevene svarer: «Masete», «Hun ville ha alt», «Hun vil ha en drage og så vil hun aldri mer ha en drage», «Hun ble sur og sint», «Og så kalte hun faren sin for dust». Gjennom elevenes utsagn ser vi at de har dannet et indre bilde av hvem prinsessa $i$ denne fortellingen er, basert på detaljer i teksten.

I starten av Barbie-Nils \& pistolproblemet (Tinnen \& Kanstad Johnsen, 2011) er det et oppslag som viser Nils og faren på vei til leketøysbutikken:

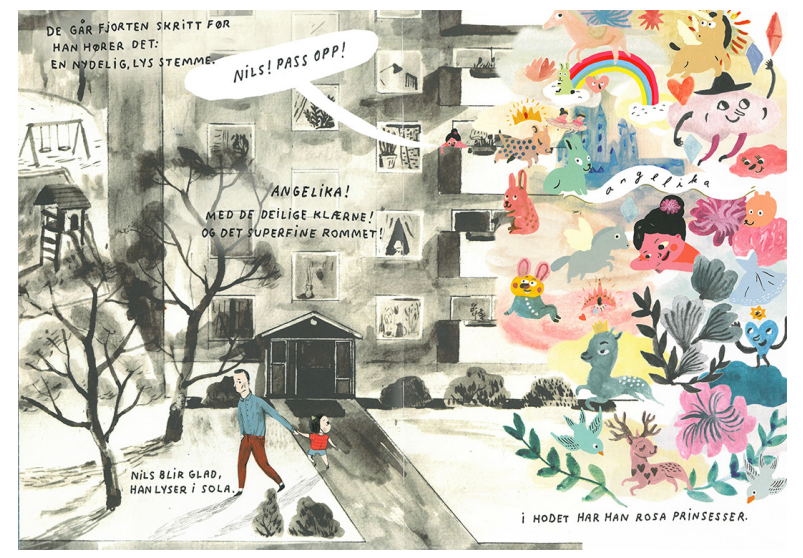

Bilde 2. Gjengitt fra Tinnen og Kanstad Johnsen (2011) med tillatelse fra illustratør og forlag. 
Læreren leser teksten, og så spør hun elevene: “'I hodet har han rosa prinsesser.' Hva tror dere det betyr?» (Spørsmål 9). En elev svarer "Vet ikke», mens en annen elev svarer: «At han er forelska». Dette siste svaret viser at eleven tolker det metaforiske og billedlige uttrykket som en følelse og at i denne sammenhengen er følelsen forelskelse. Kanskje gjør eleven denne fortolkningen med utgangspunkt i ordet «prinsesse» og «rosa». Fortolkningen kan også forankres i den delen av bildet hvor rosafargen er dominerende og hvor Nils og venninnen, som ligger på en rosa sky, sender hverandre lengtende blikk.

Flere steder i materialet ser vi eksempler på at ett og samme bilde utløser forskjellige fortolkninger, alt etter hvilken kunnskap og hvilke erfaringer som blir aktivert i elevenes møte med bildet (jf. leserens disposisjoner). Bildene har altså et semiotisk potensiale som kan realiseres på ulike måter. Noen elever fokuserer for eksempel på detaljer i illustrasjonene - løsrevet fra den overordnede fortellingen noe som både viser at elevene har andre referanser enn det voksne har, og at «bildets språk» - hvordan bildet er satt sammen - påvirker elevenes fortolkinger. Elevenes ulike fortolkinger framviser flere fortolkingsmuligheter, og tekstene viser dermed et stort potensiale for ulike forestillingsverdener.

\section{På veg ut av teksten}

Vi finner også flere eksempler på det Langer kaller for «å stige ut og tenke over hva en vet», og elevenes fortolkninger er både knyttet til enkeltoppslag, men også til den overordnede fortellingen i boka. I Dragejakten (Ousland, 2011) spør læreren: «Syntes dere synd på noen av personene i denne boka? (spørsmål 12). En elev svarer umiddelbart: «Kongen», og læreren følger opp med spørsmålet «Hvorfor?». Eleven utdyper svaret sitt på denne måten: «Fordi hun [prinsessa] ikke setter pris på gavene og fordi hun sa dumming til kongen». Dette viser at eleven gjør en personkarakteristikk basert på karakterens handlinger og utsagn selv om prinsessen aldri blir omtalt som bortskjemt i teksten.

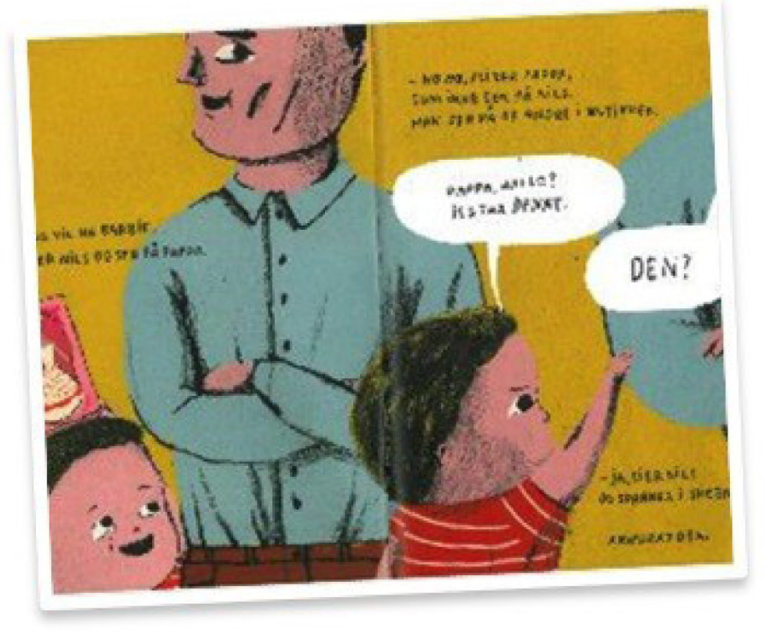

Bilde 3. Gjengitt fra Tinnen og Kanstad Johnsen (2011) med tillatelse fra illustratør og forlag. 
I Barbie-Nils \& pistolproblemet (Tinnen \& Kanstad Johnsen, 2011) er det et oppslag som viser Nils og pappa inne i leketøysbutikken, hvor Nils har funnet den leken han ønsker seg.

«Hø, hø, flirer pappa, som ikke ser på Nils. Han ser på de andre i butikken», leser læreren. I manualen ber vi læreren om å stille et spørsmål som inviterer elevene til å stige ut og tenke over hva de vet knyttet til akkurat dette oppslaget: «Hvorfor tror dere pappa bare ler og ser på de andre i butikken?» (Spørsmål 14). En elev svarer: «På grunn av at han tror det er pinlig å leke med det [Barbie].» Med dette svaret viser eleven at han overfører erfaring fra en kjent situasjon til en ukjent og er aktiv medskaper av teksten. Eleven viser en forståelse av situasjonen, at det å kjøpe Barbiedukke for en gutt, kan oppleves som et normbrudd. Dette kan være basert på egne erfaringer og observasjoner, men det kan vi ikke si noe sikkert om. Det vi imidlertid kan se, er at tolkningen krever at eleven klarer å ta de ulike personenes perspektiv, at han kan leve seg inn i teksten og «kjenne på» andres opplevelser av situasjonen. Begge disse siste eksemplene viser at elevene greier å sette seg inn i andres situasjon og kjenne på andres følelser, noe som er et grunnleggende trekk ved litteraturlesing i følge Per Tomas Andersen. "Litteraturen gir oss muligheter til både å studere de narrative emosjoner vi er innleiret i, og til å reflektere over dem og utvikle kritiske holdninger til dem», påpeker Andersen (2011, s. 20).

Vi finner også eksempler på at elever gjør en overordnet fortolking basert på tematikken i boka, for eksempel mot slutten av Barbie-Nils $\mathcal{E}$ pistolproblemet (Tinnen \& Kanstad Johnsen, 2011), når Nils leker med den nye Barbiedukka si.

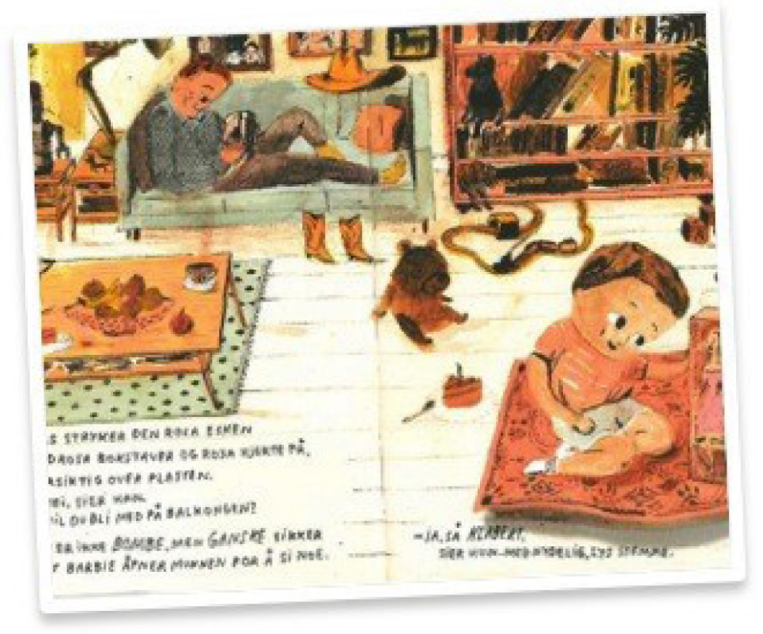

Bilde 4. Gjengitt fra Tinnen og Kanstad Johnsen (2011) med tillatelse fra illustratør og forlag.

Etter at læreren har formidlet teksten, og elevene har studert illustrasjonen, spør læreren: «Kan fortellingen fortelle oss noe?» (Spørsmål 10). Spørsmålet inviterer elevene til å tenke over hva de vet eller hva teksten dreier seg om (Hetmar, 2001), og 
spørsmålet er knyttet til hele boka, ikke bare til dette ene oppslaget. En elev svarer: «Den kan fortelle at det ikke er fint å mobbe og være slemme med folk og ikke bestemme.» Her gjør eleven en fortolkning basert på bokas overordnede plot. En kan si at eleven leser med et fokus på hva teksten dreier seg om (Hetmar, 2001), for han overfører det konkrete motivet, at Nils i følge faren ikke bør ønske seg en Barbiedukke, til en mer overordnet tematikk: ikke bestemme over hverandre, mobbing og det å være slemme mot hverandre.

\section{Ved å objektivere leseopplevelsen}

I materialet ser vi også at elevene kobler sine fortolkinger til andre tekster, de gjør det Langer kaller for «å stige ut og objektivere leseopplevelsen». For eksempel er innsidepermen i Dragejakten (Ousland, 2011) rikt illustrert, som en del av bildebokas paratekst.

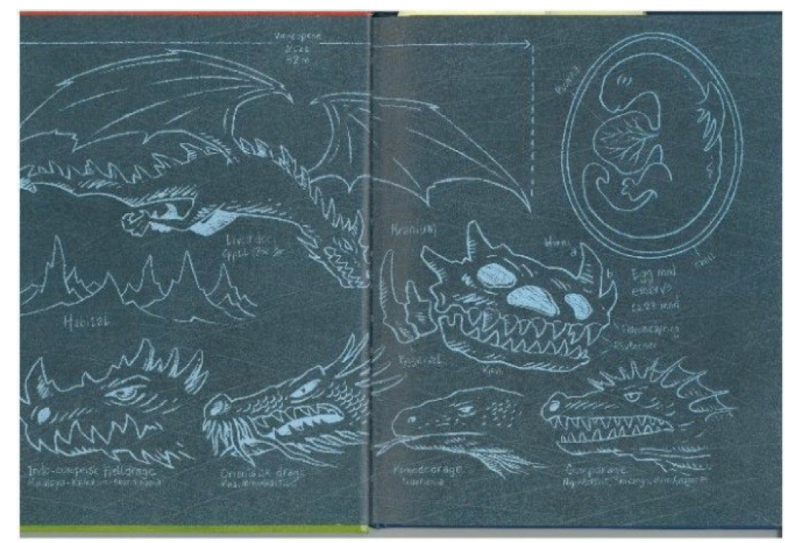

Bilde 5. Gjengitt fra Ousland (2011) med tillatelse fra illustratør og forlag.

Etter at boka er ferdig lest, stopper læreren ved oppslaget og spør: «Når dere ser på dette bildet, minner det om noe dere har sett eller lest tidligere?» (Spørsmål 17). Spørsmålet inviterer elevene til å stige ut av teksten og på den måten objektivere den. «Ja», svarer én av elevene, «fra Borgøy». «Hvor er det?» følger læreren opp. «Det er en film», svarer eleven. "Hva sa du den het?» spør læreren. «Drageridderen fra Borgøy.» ${ }^{4}$ svarer eleven. I elevens svar ser vi hvordan han sammenlikner oppslaget med fakta om drager med en film som handler om drager, og på den måten koples to ulike tekster sammen og tilfører hverandre mening, for eleven.

\section{Oppsummering}

De små utdragene fra klassesamtalene viser at elevene er i stand til å posisjonere seg som litterære lesere i norskfaget og utforske de studieobjektene som de har fått tilgang til. Elevene viser seg som faglige lesere i møte med litteratur ved at de er

\footnotetext{
${ }^{4}$ Dragerytterne fra Borkøy er en amerikansk animasjonsserie, blant annet vist på NRK-Super, basert på Dragetrener-filmen.
} 
aktive medskapere av tekst, stiller spørsmål og fremsetter hypoteser, tolker og lager forestillinger basert på egne erfaringer og tidligere leste tekster. Fortolkningene knyttes både til teksten som et litterært uttrykk og til bildene. På denne måten kan en si at også unge elever som førsteklassinger er i stand til å lese litterære tekster på en faglig måte.

\section{Muligheter og didaktiske utfordringer for elevene som litterære lesere i begynneropplæringa}

I denne studien hadde vi lagt til rette for fagspesifikk leseopplæring hvor elevene skulle få mulighet til å posisjonere seg som litterære lesere. Men dette er unge elever som har begrensa erfaringer i verden og det er derfor steder i litteraturen hvor de ikke skjønner ordene og uttrykkene som blir brukt. For å kunne fortolke tekster er det en forutsetning at elevene skjønner ordene og begrepene. Her er et eksempel fra boka Dragejakten (Ousland, 2011):

Lærer: Hva betyr tronarving?

Elev: Han som eier tronen.

Lærer: Og hva er tronen?

Elev: Der kongen sitter.

Elev: Den fineste stolen som finnes.

Og et eksempel fra boka Barbie-Nils $\mathcal{E}$ pistolproblemet (Tinnen \& Kanstad Johnsen, 2011):

Lærer: Hva er en piruett?

Elev: Slik (viser en piruett på gulvet).

Lærer: Det er en piruett, når de snurrer slik.

Vi hadde lagt til rette for en leseopplæring som skulle gi elevene muligheter til å utforske bildebøkene på en fagspesifikk måte. Men de generelle og de spesialiserte lese- og skrivepraksisene trenger ikke å stå i vegen for hverandre. Forskning, som hos Fang \& Coatam (2013), har vist at generelle og spesialiserte skrivepraksiser kan utfylle hverandre, og at elever kan lære både generell og spesifikk lesing samtidig. Vi mener at studien vår har vist at det er mulig for også de yngste elevene å være deltakere i fagspesifikk leseopplæring i norskfaget. De litterære samtalene vi har presentert gjennom et utvalg eksempler legger til rette for at elevene skal kunne være aktive medskapere av tekst, danne hypoteser, uttale seg om hva teksten dreier seg om og se tekster i lys av andre tekster. Slik fagspesifikk tilnærming er også avhengig av generell leseopplæring som eksempelvis å forklare hva ord betyr.

En utfordring med studien er knyttet til samtalen som arbeidsform. Klassesamtalen rundt bildeboka Barbie-Nils \& pistolproblemet (Tinnen \& Kanstad Johnsen, 2011) har et sterkt intervjupreg, det vil si at den kjennetegnes av et spørsmål-svar-mønster (Hoel, 2014). I samtalen finnes en rekke eksempler på at læreren bekrefter enkeltelevers innspill, men hun viderefører dem ikke, og dermed begrenser hun elevenes mulighet for videre utforsking av teksten: 
Lærer: Hva tror du Jonas?

Elev: At han er forelsket.

Lærer: At han er forelsket.

Fortsetter å lese.

Et annet karakteristisk trekk ved samtalen rundt Barbie-Nils og pistolproblemet (Tinnen \& Kanstad Johnsen, 2011), som er med på å underbygge intervjupreget, er at i stedet for å invitere til klassesamtale, fordeler læreren ordet til enkeltelever, som «Hva tror du, Jonas?», «Hva tenker du Markus?». Det ser ut til å være lærerens styring av samtalen, gjennom manglende videreføring og fordeling av ordet, som resulterer i spørsmål-svar-mønsteret. Elevene på sin side, fortolker oppgaven de blir gitt dit hen at de skal svare knapt, og kanskje til og med korrekt, på lærerens direkte henvendelser, og en konsekvens er at bidragene deres i samtalen framstår som knappe beskrivelser heller enn utforskende fortolkninger.

Dessuten kan samtaleformen virke direkte forstyrrende på den litterære opplevelsen, og vi finner elevuttalelser som: «Okei, kan du være så snill å ikke stoppe mer?», «Du må lese også, ikke bare forklare.», «Ikke still noen spørsmål da!». Denne siste elevuttalelsen er også en kritikk til oss og manualen vi har utarbeidet, som nok hadde vel mange lesestopp med spørsmål.

Er lesinga av Barbie-Niels $\mathcal{E}$ pistolproblemet (Tinnen \& Kanstad Johnsen, 2011) en klassesamtale eller er det et intervju? I materialet ser vi mange åpninger for samtale, men læreren bekrefter og viderefører i liten grad elevenes utsagn. Selv om læreren har fått en manual som ivaretar dette, greier hun ikke fullt ut å bidra til elevenes utforsking av teksten. Spørsmålene blir kontrollspørsmål og eleven er stadig utenfor teksten på veg inn. Skyldes dette boka, læreren, elevene, eller et det en mangel ved designet av denne studien? Intervjuformen som preger denne samtalen kan nok like gjerne skyldes presset av det å bli forsket på, og at vi ikke forsikret oss om en felles forståelse av hvordan samtalen skulle gjennomføres og hvilket handlingsrom lærerne hadde.

Til tross for disse didaktiske utfordringene knyttet til generell kontra spesifikk leseopplæring og selve samtaleformen med læreren som noe vel styrende i klassediskusjonene, mener vi at elevene har et potensiale for å nærme seg litterære tekster med et analytisk blikk. Men elevene trenger øvelse og erfaring, gjerne gjentatte lesinger av samme bok. Slik kan de virkelig få anledning til å utforske teksten, gå i dybden både i tekst og bilder og supplere gamle oppdagelser med nye. I denne studien var det kun tre av elevene som hadde møtt en av bøkene tidligere og da ikke i en skolesammenheng. Elevene trenger både erfaring med litterære tekster og med klassesamtalen om litteratur (jf. Hennig, 2012). Det å diskutere og utforske tekster er en diskursiv praksis som skolen etter hvert stiller store krav til.

Designet for denne studien har hatt som mål å få svar på spørsmålet «Hvordan posisjonerer elevene seg som litterær lesere på 1. trinn?». Elevenes respons viser at dette er en diskurs som de kan bidra i. $\AA$ bruke Langers teorier om forestillingsverdener kan være en tilnærmingsmåte som læreren kan utvikle i møte med andre tekster, og på den måten legge til rette for litterær lesekompetanse allerede $\mathrm{i}$ 


\section{norskfagets begynneropplæring. Dermed kan elevene få erfaring med og øvelse i å} utforske tekster.

\section{Litteratur}

Aase, L. (2005). Litterære samtalar. I B. K. Nicolaysen \& L. Aase (Red.). Kulturmøte i tekstar. Litteraturdidaktiske perspektiv. Oslo: Det Norske Samlaget.

Andersen, P.T. (2011). Hva skal vi med skjønnlitteraturen i skolen? Norsklcereren 2/2011, s. $15-22$.

Berge, K. L. (2005). Skriving som grunnleggende ferdighet og som nasjonal prøve - ideologi og strategier. I A.J. Aasen og S. Nome. Det nye norskfaget. LNU/Fagbokforlaget. s. 161-188.

Carter, M. (2007). "Ways of Knowing, Doing and Writing in the Disciplines.". College Composition and Communication, 58(3), 385-417.

Damico, J., Baildon, M., Exter, M., \& Guo, S. (2009). Disciplinary literacy in a ninth-grade studies classroom. Fournal of Adolenscent $\mathcal{E}$ Adult Literacy, 53(4), 325-335.

Fagella-Luby, M., Graner, P.S., Desbler, D., \& Drew, V. (2012). Building a House on Sand. Why Disciplinary Literacy Is Not Sufficient to Replace General Strategies for Adolescent Learners Who Struggle. Topics in Lang Disorders, 32(1), 69-84.

Fang, Z. (2012). Language Correlates of Disciplinary Literacy. Topics in Language Disorders., 32(1), $19-34$.

Fang, Z., \& Coatoam, S. (2013). Disciplinary Literacy. What You Want to Know About It. Fournal of Adolenscent $\mathcal{E}$ Adult Literacy, 56(8), 627-632.

Fjørtoft, H. (2013). Nærlesing på ungdomstrinnet. Norsklereren, 4/2013, s. 18-24.

Harré, R., \& Langenhove, L.v. (1999). Positioning theory: moral contexts of intentional action. Oxford, Blackwell.

Harvey, S., \& Goudvis, A. (2007). Strategies That work. Teaching Comprehension for Understanding and Engagement. Maine: Stenhouse Publisher, Ontario: Pembroke Publisher Limited.

Heller, R. (2011). In Praise of Amateurism: A Friendly Critique of Moje's "Call for Change" in secondary Literacy. Fournal of Adolenscent $\mathcal{E}$ Adult Literacy, 54, 4.

Hennig, Å. (2012). Effektive lesere snakker sammen: innføring i littercere samtaler. Oslo: Gyldendal Akademisk Forlag.

Hetmar, V. (2001). «Jeg vidste ikke at stjernerne kunne le»: om litterturundervisning på mellomtrinnet, Arboka Littertur for barn og unge, 9-19. Oslo: Samlaget.

Hetmar, V. (2009). Faglig læsning og skriving i skolen - Diskurser, positioneringer og rekontekstualiseringer. I S.V. Knudsen, D. Skjelbred \& B. Aamotsbakken (Red.), Lyspå lesing. Lesing av fagtekster (s. 33-48). Oslo: Novus Forlag.

Hoel, T. (2014). 6- og 7-åringers muntlige fortellinger basert på ei ordløs bildebok. Fortelling, barn, bildebok. Doktorgradsavhandling, Universitetet i Stavanger.

Håland, A. (2016). (submitted). Disciplinary literacy in elementary school: How a struggling student positions herself as a writer. Reading Teacher.

Iser, W. (1974). The implied reader. Patterns of communication in prose fiction from Buyan to Beckett. Baltimore og London: The Johns Hopkins University Press.

Juel, C., Hebard, H., Haubner, J.P., Moran, M., (2010). Reading Through. Understanding how to think like a scientist, writer or historian can provide students with new insights as the tackle a text. Educational Leadership. www.ascd.org

Kittang, A., \& Aarseth, A. (1979). Hermeneutikk og litteratur. Oslo: Universitetsforlaget.

Kristeva, J., \& Moi, T. (1986). The Kristeva reader. New York, Columbia University Press.

Krogh, E. (2011). Undersøgelser af fag i et fagdidaktisk perspektiv. I E. Krogh \& F.V. Nielsen (Red.) Sammenlignende fagdidaktikk, 33-49. Aarhus: Aarhus Universitet.

Langer, J.A. (2005). Litterära föreställningsvärldar: litteraturundervisning och litterär förståelse. Göteborg: Daidalos.

Moje, E.B. (2008). Foregrounding the Disciplines in Secondary Literacy Teaching and Learning: A call for Change. Fournal of Adolescent $\mathcal{E}$ Adult Literacy, 52(2), 96-107.

Monte-Sano, C., De La Pas, S., \& Felton, M. (2014). Implementing a disciplinary-literacy curriculum for US history:learning from expert middle school teachers in diverse classrooms. Fournal of Curriculum Studies, $46(4), 540-575$.

Monte-Sano, C. (2010). Disciplinary literacy in history: An exploration of the historical nature of adolenscents' writing. Fournal of the Learning Sciences, 19(4), 539-568.

National Reading Panel (2000). Teaching children to Read: An evidence-Based Assessment of the Scientific Research Literature on Reading and Its Implications for Reading Instruction. 


\section{Anne Håland og Trude Hoel}

Nilsen, I., Gouvervennec, A. \& Skaftun, A. (2014). Lesing i norsk. I A. Skaftun, O.J. Solheim og P.H. Uppstad (Red.). Leseboka. Leseopplcering $i$ alle fag på ungdomstrinnet. Oslo: Cappelen Damm Akademisk.

NOU 2015:8. Fremtidens skole. Fornyelse av fag og kompetanser. Kunnskapsdepartementet.

Ousland, B. (2011). Dragejakten. Oslo: Cappelen Damm.

Rødnes, K.A. (2011). Elevers meningsskaping av norskfaglige tekster $i$ videregående skole. $\mathrm{PhD}$-thesis, Universitetet i Oslo.

Sandvik, L.V., Engvik, G., Fjørtoft, H., Langseth, I.D., Aaslid, B.E., Mordal, S. \& Bjuland, T. (2012). Vurdering $i$ skolen. Intensjoner og forståelse. Delrapport 1 fra prosjektet Forskning på individuell vurdering $i$ skolen (FIVIS). Trondheim: NTNU Skole- og læringsforskning.

Sandvik, L.V. \& Buland, T. (Red.). (2013). Vurdering $i$ skolen. Operasjonaliseringer og praksiser. Delrapport 2 fra prosjektet Forskning på individuell vurdering $i$ skolen (FIVIS). Trondheim: NTNU Skole- og læringsforskning.

Shanahan, T. \& Shanahan, C. (2008). Teaching disciplinary literacy to adolescents: Rethinking content-area literacy. Harvard Educational Review, 78(1), s. 40-61.

Shanahan, T. \& Shanahan, C. (2012). What is disciplinary literacy and why does it matter? Topics in Language Disorders, 32(1), s. 7-18.

Shanahan, C., \& Shanahan, T. (2014). The Implication of Disciplinary literacy. Fournal of Adolenscent E Adult Literacy, 57 (8), s. 628-631.

Shanahan, C. (2015). Disciplinary Literacy Strategies in Content Area Classes. International Literacy Assosiation. DOI: 10.1598/e-ssentials.8069

Skaftun, A. (2009). Litteraturens nytteverdi. Bergen: Fagbokforlaget.

Taube, K., Fredriksson, U., \& Olofsson, Å. (2015). Kunskapsöversikt om läs- och skrivundervisning för yngre elever. Vetenskapsrådets rapporter.

Tinnen, K., \& Johnsen, M.K. (2011). Barbie-Nils $\mathcal{E}$ pistolproblemet. Oslo: Gyldendal.

Vacca, R.T., Vacca, J.A., \& Mraz, M. (2011). Content area reading. Literacy and learning across the curriculum (10th ed.). Boston: Pearson.

Weinstein, C.E. \& Mayer, R.E. (1986). The teaching of learning strategies. I M.C.R. Wittrock (Red.), Handbook of research on teaching. New York: Macmillian.

Yin, R.K. (2009). Case study research: design and methods. Thousand Oaks, Calif., Sage. 